\title{
Valorisation of Waste Wood Biomass as Biosorbent for the Removal of Synthetic Dye Methylene Blue from Aqueous Solutions
}

\author{
Natalija Velić ${ }^{1}$, Marija Stjepanović ${ }^{*}$, Lidija Begović ${ }^{2}$, Mirna Habuda-Stanić ${ }^{1}$, Darko Velić ${ }^{1}$, Tamara Jakovljević ${ }^{3}$
}

(1) Josip Juraj Strossmayer University of Osijek, Faculty of Food Technology Osijek, Franje Kuhača 20, HR-31000 Osijek, Croatia; (2) Josip Juraj Strossmayer University of Osijek, Department of Biology, Cara Hadrijana 8/A, HR-31000 Osijek, Croatia; (3) Croatian Forest Research Institute, Division for Forest Ecology, Cvjetno naselje 41, HR-10450 Jastrebarsko, Croatia

* Correspondence: e-mail: marija.nujic@ptfos.hr
Citation: VELIĆ $N$, STJEPANOVIĆ $M$, BEGOVIĆ L, HABUDA-STANIĆ M, VELIĆ D, JAKOVLJEVIĆ T 2018 Valorisation of Waste Wood Biomass as Biosorbent for the Removal of Synthetic Dye Methylene Blue from Aqueous Solutions. South-east Eur for 9 (2): 115-122. DOI: https://doi. org/10.15177/seefor.18-13

Received: 30 Jul 2018; Revised: 16 Oct 2018; Accepted: 28 Oct 2018; Published online: 26 Nov 2018

\begin{abstract}
Background and Purpose: Wood and wood processing industries are generators of a substantial amount of waste wood biomass, such as wood chips, shavings and sawdust. Such waste is often unused and its disposal can be a serious environmental problem. Different lignocellulosic waste materials have been successfully used as low-cost adsorbents (biosorbents) for the removal of synthetic dyes, as well as other contaminants, from wastewater. The aim of this study was to valorise the waste wood biomass of ten tree species, out of which seven are the most represented species of the Croatian growing stock, as biosorbents for the removal of synthetic dye methylene blue (MB) from model solutions.

Materials and Methods: The waste wood biomasses (shavings or sawdust) of ten tree species, namely common beech, pedunculate oak, sessile oak, common hornbeam, narrow-leafed ash, poplar, European silver fir, Norway spruce, European larch and Douglas fir, were dried and milled prior to characterisation and adsorption experiments. Characterisation of the biosorbents was performed by chemical analysis and Fourier transform Fourier transform infrared spectroscopy (FTIR). Upon characterisation, batch adsorption experiments were conducted in order to survey waste wood biomass as potential adsorbents for the removal of synthetic dye MB. The colour removal was monitored spectrophotometrically at predetermined time intervals. Further adsorption experiments were performed using poplar sawdust. The effects of contact time, biosorbent concentration, initial dye concentration, and $\mathrm{pH}$ on the adsorption process were investigated. The experimental data obtained by batch adsorption experiments were analysed using adsorption isotherm models (Freundlich and Langmuir).

Results: All the tested biosorbents were found to be very effective for the removal of MB from model dye solution, achieving high removal percentages ranging from 93.25 to $98.50 \%$. Poplar sawdust proved to be the most effective. It was shown that $\mathrm{MB}$ adsorption process onto poplar sawdust could be interpreted in terms of Langmuir and Freundlich adsorption isotherm models.

Conclusions: Taken together, these results suggest that waste wood biomass has the potential to be used as a low-cost biosorbent for MB removal from aqueous solutions.
\end{abstract}

Keywords: adsorption, dye removal, Methylene Blue, poplar sawdust, waste wood biomass

\section{INTRODUCTION}

Wood is a natural renewable material that can have different purposes (e.g. construction material, fuel, etc.) and can be transformed into many different products. Depending on the geographical area, different tree species are prevalent in that specific area. The prevalent species of Croatian growing stock are the following: $36 \%$ common beech (Fagus sylvatica L.), 12\% pedunculate oak (Quercus robur L.), 10\% sessile oak (Quercus petraea (Matt.) Liebl.), 9\% common hornbeam (Carpinus betulus L.), 8\% European silver fir (Abies alba Mill.), 3\% narrow-leafed ash (Fraxinus angustifolia Vahl) 
and 2\% Norway spruce (Picea abies Karst.). All other tree species make up the remaining 20\% [1]. Apart from the use of wood as fuel, there are four major sectors in the EU forestbased industries: woodworking, furniture, pulp and paper manufacturing and converting, and printing [2]. Since the industries that use forest wood are relatively heterogeneous, so are the resulting production waste streams. Wood processing residues (waste) remaining after processing logs and timber include bark, shavings, offcuts, sawdust, etc., and the amount of generated residues can be substantial. It can be converted into fuels in form of briquettes and pellets or can be used for the generation of electricity. Even though wood processing waste is available throughout the year and is relatively cheap, it often remains unutilised and its disposal can be a serious environmental problem. One of the possible uses of wood processing waste, besides its use as fuel, can be the use as low-cost adsorbents (biosorbents) for the removal of pollutants, such as synthetic dyes, from wastewater.

Synthetic dyes are widely used in almost all industries, from textile to food industry. Since the excess dye left after the dyeing processes ends up in the industrial effluents, the dyes are recognised as the most common water pollutants that detrimentally affect the aquatic life [3]. They also exhibit recalcitrance towards removal/biodegradation by conventional biological wastewater treatment methods. The method most often employed for the removal of dyes is adsorption using conventional adsorbents, such as activated carbon [4]. However, despite their remarkable adsorption capacities, the application of conventional adsorbents is often limited by high price. It is, therefore, of great importance to find inexpensive (low-cost) adsorbents that could replace the costly conventional ones. By definition, the low-cost adsorbent is abundant in nature or is an industrial by-product or waste material that requires little or no processing [5]. Lignocellulosic waste materials originating from wood and agri-food industry have the potential to be used as low-cost adsorbents, among which sawdust is one of the most appealing materials when it comes to removing dyes from wastewater [6]. Sawdusts of different tree species were investigated as adsorbents for the removal of dyes: meranti wood for methylene blue removal [7], beech wood sawdust for direct brown removal [8], chir pine sawdust for Congo red and basic violet 1 removal [9], etc.

The synthetic dye used as a model in this study is a cationic (basic) dye methylene blue (MB) (Figure 1), widely used for cotton, silk and leather dyeing [10], as well as in microbiology for staining and in medicine for the treatment of hypotension, hypoxia, as antimalarial and more [11]. MB is not strongly hazardous, but it can still cause harmful effects in humans and animals.

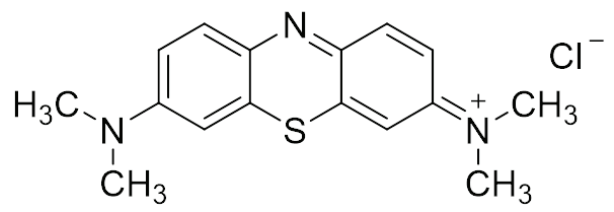

FIGURE 1. The chemical structure of methylene blue (MB).
The overall purpose of this study was to valorise the waste wood biomass of ten tree species of the Croatian growing stock as biosorbents for the removal of dye $M B$ from aqueous solution. Upon survey of ten tree species, the aim was to further investigate the most efficient species (i.e. poplar) regarding different conditions for the adsorption of $\mathrm{MB}$, namely contact time, biosorbent concentration, initial dye concentration and solution $\mathrm{pH}$.

\section{MATERIALS AND METHODS}

\section{Biosorbent}

Waste wood biomass (wood shavings and sawdust) was kindly donated by Croatian Forests Ltd. Collected waste wood biomass included ten tree species, namely common beech, pedunculate oak, sessile oak, common hornbeam, narrow-leafed ash, poplar (Populus euroamericana DodeGuinier), European silver fir (Abies alba Mill.), Norway spruce, European larch (Larix decidua Mill.) and Douglas fir (Pseudotsuga menziesii Mirb.).

The samples were oven dried at $323.15 \mathrm{~K}$ for 48 hours and ground using standard laboratory knife mill with $1 \mathrm{~mm}$ screen (MF10 basic, IKA Labortechnik, Germany) to ensure the particle size of adsorbent below $1 \mathrm{~mm}$. No other chemical or physical treatments were applied prior to adsorption experiments.

\section{Adsorbate}

MB was purchased from Merck. A stock solution of 100 $\mathrm{mg} \cdot \mathrm{dm}^{-3}$ of dye was prepared daily, while the experimental solutions were obtained by diluting the stock solution to the desired dye concentration.

\section{Adsorbent Characterisation}

The elemental composition $(\mathrm{C}, \mathrm{H}$, and $\mathrm{N}$ ) was performed using a CHNS/O elemental analyzer Seria II (Perkin Elmer, USA). The determination of ash content and extractives was described elsewhere [12]. The Kjeldahl method was used for protein content determination. Point of zero charge $\left(\mathrm{pH}_{\mathrm{pzc}}\right)$ was determined according to the method given in Burevska et al. [13]. Crystalline cellulose content was determined according to Foster et al. [14].

The surface functional groups affecting the adsorption process were detected by Fourier transform infrared (FTIR) spectrometer (Cary 630, Agilent Technologies, USA). The spectra were recorded from 4000 to $500 \mathrm{~cm}^{-1}$.

\section{Adsorption Studies}

\section{A Survey of Waste Biomass of Different Wood Species for} Adsorptive MB Removal

Batch adsorption experiments were carried out to investigate $\mathrm{MB}$ adsorption on different wood species' biomass by adding a fixed amount of biosorbent $(0.25 \mathrm{~g})$ to $25 \mathrm{~cm}^{3}$ of $50 \mathrm{mg} \cdot \mathrm{dm}^{-3}$ dye solution taken in a $100 \mathrm{~cm}^{3}$ Erlenmeyer flask. The $\mathrm{pH}$ was not adjusted; however, it was measured at the beginning and at the end of the adsorption process using the $\mathrm{pH}$-meter (Seven Easy, Mettler Toledo). The flasks were placed in the thermostatic shaker (SW22, Julabo) at 298.15 $\mathrm{K}$ and $150 \mathrm{rpm}$ for $120 \mathrm{~min}$, to ensure the equilibrium was reached. The samples were taken at predetermined time 
intervals for spectrophotometric determination of colour removal. The samples were filtered through Whatman filter paper No. 42 and then centrifuged at $6000 \mathrm{rpm}$ for $5 \mathrm{~min}$ (IKA mini G). The dye concentrations in clarified supernatants were determined spectrophotometrically (Specord 200, Analytic Jena) at $664 \mathrm{~nm}$. The percent of dye removal was calculated as follows:

$$
\% \text { dye removal }=\left[\frac{\left(\gamma_{0}-\gamma\right)}{\gamma_{0}}\right] \cdot 100
$$

where $\gamma_{0}$ and $\gamma\left(\mathrm{mg} \cdot \mathrm{dm}^{-3}\right)$ are the initial dye concentration and dye concentration after predetermined contact time, respectively. The amount of dye adsorbed at equilibrium onto biosorbents, $q_{e}\left(\mathrm{mg} \cdot \mathrm{g}^{-1}\right)$, was calculated using the following equation:

$$
q_{\mathrm{e}}=\frac{\left[\left(\gamma_{0}-\gamma_{\mathrm{e}}\right) \cdot V\right]}{m}
$$

where $\nu_{e}$ is the dye concentration at equilibrium, $V$ is the dye solution volume $\left(\mathrm{dm}^{3}\right)$ and $\mathrm{m}$ is the mass of the biosorbent used (g).

\section{Adsorption Studies using Poplar Sawdust as Biosorbent}

Based on the results of a survey of different tree species as biosorbents for MB removal, poplar sawdust was used in further adsorption experiments. The effect of biosorbent concentration and $\mathrm{pH}$ on the amount of adsorbed MB was tested for different biosorbent concentrations ranging from 2 to $10 \mathrm{~g} \cdot \mathrm{dm}^{-3}$. To study the effect of the initial dye concentration on the amount of adsorbed dye, the experiments were carried out at the temperature of 298.15 $\mathrm{K}$, biosorbent concentration of $4 \mathrm{~g} \cdot \mathrm{dm}^{-3}, 150 \mathrm{rpm}$ and $\mathrm{pH}=7$ for $120 \mathrm{~min}$. The initial MB concentrations were as follows: $10,30,50$ and $100 \mathrm{mg} \cdot \mathrm{dm}^{-3}$. The effect of $\mathrm{pH}$ was tested in the $\mathrm{pH}$ range from 4.0 to 9.0 , while all the other parameters were kept constant (initial dye concentration of $50 \mathrm{mg} \cdot \mathrm{dm}^{-3}$, biosorbent concentration of $4 \mathrm{~g} \cdot \mathrm{dm}^{-3}, 298.15 \mathrm{~K}, 150 \mathrm{rpm}$ and $120 \mathrm{~min}$ ). The $\mathrm{pH}$ was adjusted using $0.1 \mathrm{~mol} \cdot \mathrm{dm}^{-3} \mathrm{NaOH}$ and $0.1 \mathrm{~mol} \cdot \mathrm{dm}^{-3} \mathrm{HCl}$ solutions. The experimental data obtained by batch adsorption experiments were analysed using linear forms of Langmuir and Freundlich adsorption models.

All the experiments were performed in duplicate and were found reproducible.

\section{RESULTS AND DISCUSSION}

\section{Biosorbent Characterization}

The chemical composition of waste wood biomass of the surveyed tree species is given in Table 1 . The results of the elemental analysis revealed that all used tree species have similar obtained $\mathrm{C}$ and $\mathrm{H}$ values ranging from 44.51 to $47.60 \%$ and 5.94 to $6.38 \%$, respectively. This is in agreement with the research by Nacu [15] that reported similar values for total carbon and hydrogen. The chemical elements mentioned above, which are present in relatively large quantities, can form (along with oxygen and nitrogen) functional groups at the surface of sawdust that can serve as potential dye binding centres [16]. The nitrogen content varied from 0.07 to $0.44 \%$, while protein content varied from 0.24 to $1.06 \%$. Wood is comprised of major chemical components which are cellulose (40-45\%), hemicellulose (30\%) and lignin (20-30\%), while extractives, ash, proteins and other components make up the rest [17]. The content of cellulose in this study was in the range from 31.66 to 44.27 . Extractives include, amongst others, lipids, phenolic compounds, terpenoids, fatty acids, resin acids, steryl esters, sterol and waxes and their content generally varies between $2 \%$ and $5 \%$, but can even reach $15 \%$ [18]. In this study, the content of extractives ranged from 1.31 to $3.94 \%$. Ash is the inorganic residue remaining after water and organic matter have been removed, which provides a measure of the total amount of minerals within a sample. The ash content of wood biomass can vary between tree species and tree components [19]. High ash content can decrease the heating value of biomass [20]. Abdolali et al. [21] reported the average ash content of hardwood and softwood of less than $1 \%$. However, in this study, the determined ash contents were higher and ranged from 0.81 to $1.9 \%$.

The surface chemistry of adsorbents is determined by the acidic or basic character of their surface, or in other words, the net charge of the adsorbent surface can play a crucial role in the interactions occurring during the adsorption process. The $\mathrm{pH}$ at which the adsorbent surface net charge is zero is defined as the point of zero charge $\left(\mathrm{pH}_{\mathrm{pzc}}\right)$. When solution $\mathrm{pH}$ is lower than $\mathrm{pH}_{\mathrm{pzc}}$ the adsorbent surface is positively charged and can interact with anions, while at $\mathrm{pH}$ higher than $\mathrm{pH}_{\mathrm{pzc}}$ the adsorbent surface is charged negatively and can interact with cations [22]. The $\mathrm{pH}_{\mathrm{pzc}}$ of all used biosorbents was in the range from 5.25 to 7.10 .

\begin{tabular}{|c|c|c|c|c|c|c|c|c|c|c|}
\hline Parameter & $\begin{array}{c}\text { Common } \\
\text { beech }\end{array}$ & $\begin{array}{l}\text { Pedunculate } \\
\text { oak }\end{array}$ & $\begin{array}{c}\text { Cornish } \\
\text { oak }\end{array}$ & $\begin{array}{c}\text { Common } \\
\text { hornbeam }\end{array}$ & $\begin{array}{c}\text { Narrow- } \\
\text { leafed } \\
\text { ash }\end{array}$ & Poplar & $\begin{array}{c}\text { European } \\
\text { silver fir }\end{array}$ & $\begin{array}{c}\text { Norway } \\
\text { spruce }\end{array}$ & $\begin{array}{c}\text { European } \\
\text { larch }\end{array}$ & $\begin{array}{c}\text { Douglas } \\
\text { fir }\end{array}$ \\
\hline$C(\%)$ & 44.64 & - & 46.31 & 46.77 & 44.51 & 46.44 & - & 47.30 & 47.60 & 47.40 \\
\hline $\mathrm{H}(\%)$ & 6.38 & - & 6.33 & 6.23 & 5.94 & 6.29 & - & 6.35 & 6.34 & 6.22 \\
\hline $\mathrm{N}(\%)$ & 0.33 & - & 0.08 & 0.16 & 0.30 & 0.21 & - & 0.44 & 0.31 & 0.44 \\
\hline Extractives* (\%) & 1.41 & 3.48 & 3.94 & 1.64 & 3.18 & 2.45 & 1.72 & 1.31 & 1.36 & 2.41 \\
\hline Protein (\%) & 0.66 & 0.76 & 0.83 & 1.00 & 1.06 & 0.69 & 0.41 & 0.28 & 0.31 & 0.24 \\
\hline Ash (\%) & 1.14 & 1.12 & 0.81 & 1.40 & 1.50 & 1.43 & 1.80 & 1.90 & 1.45 & 1.60 \\
\hline Crystalline celulose (\%) & 31.66 & - & 32.91 & 39.89 & 33.04 & 40.53 & 44.27 & 38.00 & 32.18 & 43.06 \\
\hline $\mathrm{pH}_{\mathrm{pzc}}$ & 7.00 & 5.25 & 6.51 & 6.10 & 6.80 & 7.10 & 6.90 & 5.49 & 6.25 & 5.90 \\
\hline
\end{tabular}

TABLE 1. The chemical composition of waste wood biomass.

* ethanol/benzene (1:1) 
In order to investigate the functional groups present at the surface of used waste wood biomass, FTIR spectra were recorded for all samples. The spectrum for poplar sawdust, as a representative spectrum, is presented in Figure 2. As already mentioned, high contents of lignocellulosic polymers (i.e. cellulose, hemicellulose and lignin) are mostly responsible for a large number of hydroxyl groups available as binding sites for cationic dye molecules, such as MB. Hydroxyl groups, among others, are those mainly engaged in adsorption processes [21, 23]. The FTIR spectrum of poplar sawdust is dominated by the broad band at 3332 $\mathrm{cm}^{-1}$ representing hydroxyl groups. It can be ascribed to $-\mathrm{OH}$ stretching vibrations of polymers, e.g. cellulose and lignin, and it indicates free hydroxyl groups at the surface of the adsorbent. The band at $2899 \mathrm{~cm}^{-1}$ indicates the presence of $-\mathrm{CH}_{2}$ aliphatic groups stretching. At $2102 \mathrm{~cm}^{-1}$ there is a band that can be assigned to $-\mathrm{NH}$ stretching. The bands from 1505 to $1423 \mathrm{~cm}^{-1}$ indicate the presence of branchedchain aromatic radicals [24]. The intense band at $1028 \mathrm{~cm}^{-1}$ is probably representing the polysaccharides, i.e. it could be ascribed to $\mathrm{C}-\mathrm{O}, \mathrm{C}=\mathrm{C}$ and $\mathrm{C}-\mathrm{C}-\mathrm{O}$ stretching in cellulose, hemicellulose and lignin [25].

\section{Adsorption Studies}

A Survey of Waste Biomass of Different Wood Species for Adsorptive MB Removal

The results of a survey of the waste wood biomass of different tree species used as biosorbents for adsorptive MB removal are presented in Figure 3. The concentration of dye $\left(50 \mathrm{mg} \cdot \mathrm{dm}^{-3}\right)$ was selected based on the dye concentrations previously reported in textile effluents that ranged from 10 to $50 \mathrm{mg} \cdot \mathrm{dm}^{-3}[26,27]$. The results clearly show that all used biosorbents showed remarkable adsorptive capability for MB with high levels of dye removal (over $90 \%$ in all runs) under the applied experimental conditions. The initial stages of the adsorption process (first $30 \mathrm{~min}$ ) were characterised by the higher $\mathrm{MB}$ removal rates, compared to later stages when the removal rate becomes slower (data not shown). This can probably be explained by the larger unoccupied surface area available for dye adsorption at the earlier stages of the experiment [28]. Similar results were reported for MB removal using different waste lignocellulosic material [25, 29].

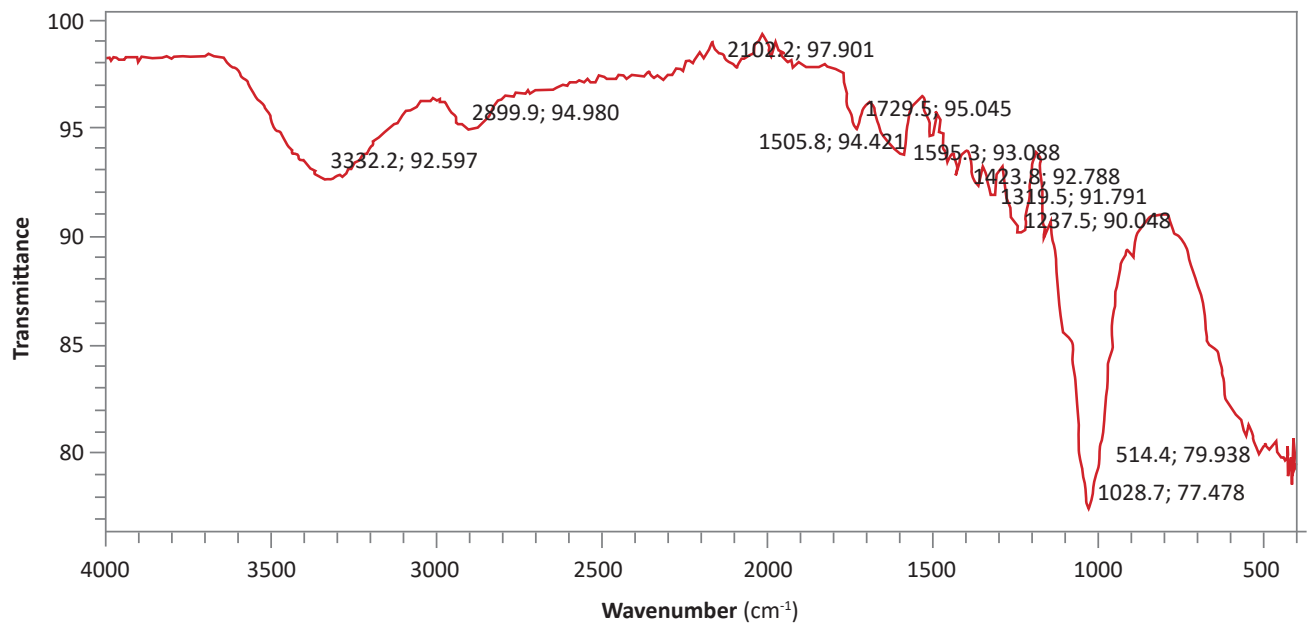

FIGURE 2. The FTIR spectral characteristics of poplar sawdust.

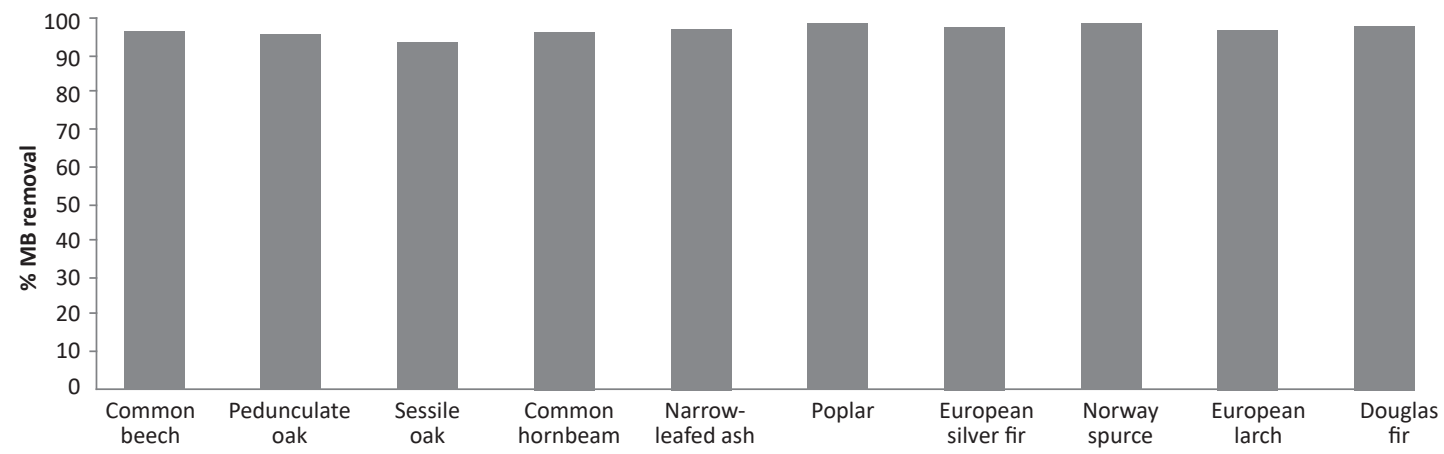

FIGURE 3. Adsorptive MB removal using different waste wood biomass as biosorbents $\left(\gamma_{\text {dye }}=50 \mathrm{mg} \cdot \mathrm{dm}^{-3}, \mathrm{t}=120 \mathrm{~min}, \mathrm{~T}=298.15\right.$ $\left.\mathrm{K}, \gamma_{\text {biosorbent }}=10 \mathrm{~g} \cdot \mathrm{dm}^{-3}, 150 \mathrm{rpm}\right)$. 
Adsorption Studies using Poplar Sawdust as Biosorbent

The adsorption process is usually strongly influenced by the adsorbent concentration because higher adsorbent concentration ensures higher surface area available for adsorption. The effect of adsorbent concentration on the adsorption of $\mathrm{MB}$ onto poplar sawdust is given in Figure 4. The results show that the percentage of $M B$ removal increased from 62 to $97 \%$ with an increase of biosorbent concentration from 2 to $10 \mathrm{~g} \cdot \mathrm{dm}^{-3}$. However, after the biosorbent concentration of $4 \mathrm{~g} \cdot \mathrm{dm}^{-3}$, the percentage removal remained almost constant over the biosorbent range of 6-10 $\mathrm{g} \cdot \mathrm{dm}^{-3}$, i.e. the further increase of biosorbent concentration did not markedly affect the adsorptive capacity. A similar behaviour was reported for $\mathrm{MB}$ removal using meranti sawdust as biosorbent [7].

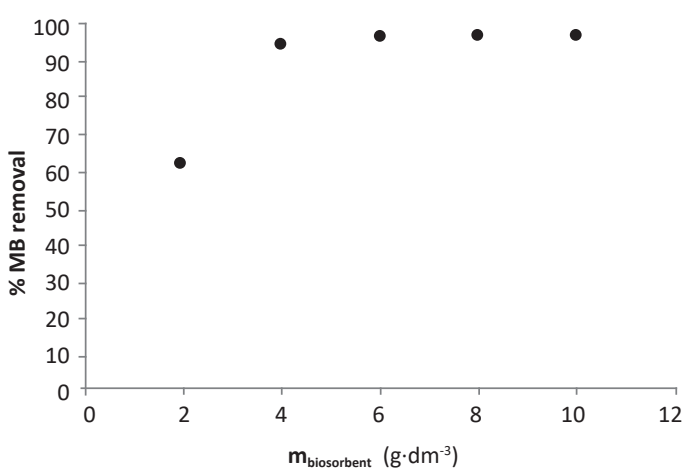

FIGURE 4. The effect of biosorbent concentration on the adsorption of $\mathrm{MB}$ onto poplar sawdust $\left(\gamma_{\text {dye }}=50 \mathrm{mg} \cdot \mathrm{dm}^{-3}\right.$, $\mathrm{t}=120 \mathrm{~min}, \mathrm{~T}=298.15 \mathrm{~K}, \mathrm{pH}=7,150 \mathrm{rpm})$.

The effect of contact time on $\mathrm{MB}$ adsorption is given in Figure 5. As already mentioned, the MB removal is rapid during the first stages and then gradually slows down until the equilibrium is reached. The equilibrium was achieved within $90 \mathrm{~min}$ and did not change with further contact time increase.

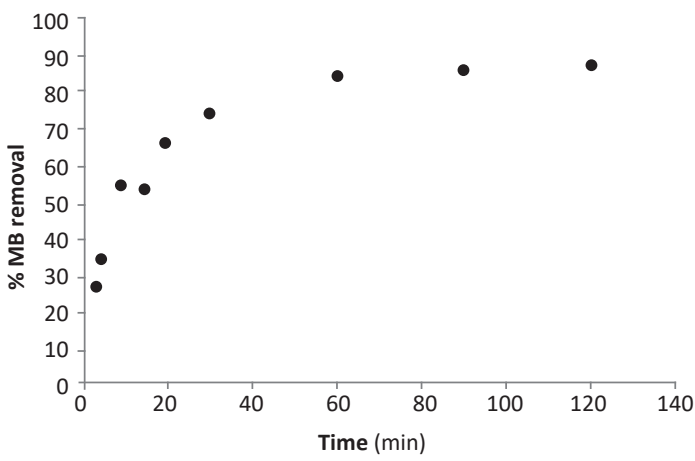

FIGURE 5. The effect of contact time on the adsorption of MB onto poplar sawdust $\left(\gamma_{\text {dye }}=50 \mathrm{mg} \cdot \mathrm{dm}^{-3}, \gamma_{\text {biosorbent }}=4 \mathrm{~g} \cdot \mathrm{dm}^{-3}\right.$, $\mathrm{t}=120 \mathrm{~min}, \mathrm{~T}=298.15 \mathrm{~K}, \mathrm{pH}=7,150 \mathrm{rpm})$.
Figure 6 shows the effect of the initial MB concentration on MB adsorption onto poplar sawdust.

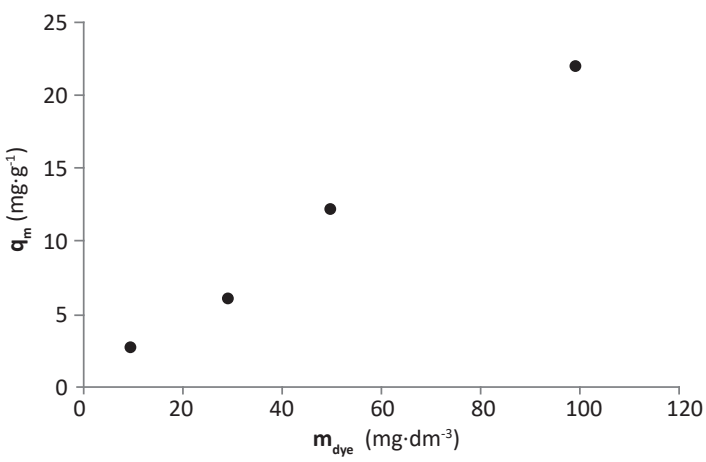

FIGURE 6. The effect of initial dye concentration on the adsorption of $\mathrm{MB}$ onto poplar sawdust $\left(\gamma_{\text {biosorbent }}=4 \mathrm{~g} \cdot \mathrm{dm}^{-3}\right.$, $\mathrm{t}=120 \mathrm{~min}, \mathrm{~T}=298.15 \mathrm{~K}, \mathrm{pH}=7,150 \mathrm{rpm}$ ).

The amount of $\mathrm{MB}$ removed at equilibrium increased from 2.41 to $21.90 \mathrm{mg} \cdot \mathrm{g}^{-1}$ when the initial MB concentration increased from 10 to $100 \mathrm{mg} \cdot \mathrm{dm}^{-3}$, which indicates that MB removal using poplar sawdust as biosorbent is concentration-dependent. This is in agreement with other studies using different waste lignocellulosic biosorbents, such as meranti sawdust [7], walnut sawdust [30] and modified Indian Rosewood sawdust [31]. Furthermore, the experimentally obtained adsorption capacities in this study are comparable to those reported by other authors, which can be seen from Table 2 .

TABLE 2. Comparison of experimentally obtained adsorption capacities of various biosorbents for MB.

\begin{tabular}{|c|c|c|}
\hline Sorption & $\begin{array}{l}\text { Adsorption capacity } \\
\qquad\left(\mathrm{mg} \cdot \mathrm{g}^{-1}\right)\end{array}$ & Reference \\
\hline $\begin{array}{l}\text { Formaldehyde treated } \\
\text { rosewood sawdust }\end{array}$ & $\begin{array}{l}11.8\left(50 \mathrm{mg} \cdot \mathrm{dm}^{-3} \mathrm{MB}\right) \\
46.1\left(250 \mathrm{mg} \cdot \mathrm{dm}^{-3} \mathrm{MB}\right)\end{array}$ & [33] \\
\hline $\begin{array}{l}\text { Chemically treated } \\
\text { rosewood sawdust }\end{array}$ & $\begin{array}{l}12.49\left(50 \mathrm{mg} \cdot \mathrm{dm}^{-3} \mathrm{MB}\right) \\
51.4\left(250 \mathrm{mg} \cdot \mathrm{dm}^{-3} \mathrm{MB}\right)\end{array}$ & [33] \\
\hline Walnut sawdust & $18.8\left(100 \mathrm{mg} \cdot \mathrm{dm}^{-3} \mathrm{MB}\right)$ & [32] \\
\hline $\begin{array}{l}\text { Pyrrole modified } \\
\text { walnut sawdust }\end{array}$ & $33.2\left(100 \mathrm{mg} \cdot \mathrm{dm}^{-3} \mathrm{MB}\right)$ & [32] \\
\hline Mansonia sawdust & $28.89\left(120 \mathrm{mg} \cdot \mathrm{dm}^{-3} \mathrm{MB}\right)$ & [34] \\
\hline Walnut sawdust & $5\left(50 \mathrm{mg} \cdot \mathrm{dm}^{-3} \mathrm{MB}\right)$ & [35] \\
\hline Cherry tree sawdust & $5\left(50 \mathrm{mg} \cdot \mathrm{dm}^{-3} \mathrm{MB}\right)$ & [35] \\
\hline Oak sawdust & $5\left(50 \mathrm{mg} \cdot \mathrm{dm}^{-3} \mathrm{MB}\right)$ & [35] \\
\hline Pitch pine sawdust & $5\left(50 \mathrm{mg} \cdot \mathrm{dm}^{-3} \mathrm{MB}\right)$ & [35] \\
\hline Meranti sawdust & $98.4\left(200 \mathrm{mg} \cdot \mathrm{dm}^{-3} \mathrm{MB}\right)$ & [7] \\
\hline Poplar sawdust & $21.9\left(100 \mathrm{mg} \cdot \mathrm{dm}^{-3} \mathrm{MB}\right)$ & This study \\
\hline
\end{tabular}


One of the important parameters affecting the adsorptive removal of different contaminants from aqueous solutions (e.g. the complex matrix such as wastewater) is $\mathrm{pH}$. The effect of $\mathrm{pH}$ on the amount of $\mathrm{MB}$ adsorbed onto poplar sawdust at equilibrium was studied over the $\mathrm{pH}$ range from 4 to 9 and the results are presented in Figure 7.

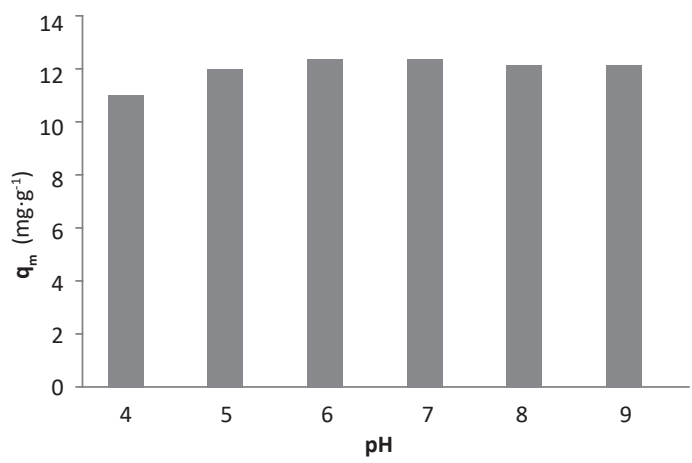

FIGURE 7. The effect of $\mathrm{pH}$ on the adsorption of $\mathrm{MB}$ onto poplar sawdust $\left(\gamma_{\text {dye }}=50 \mathrm{mg} \cdot \mathrm{dm}^{-3}, \gamma_{\text {biosorbent }}=4 \mathrm{~g} \cdot \mathrm{dm}^{-3}, \mathrm{t}=120\right.$ $\min , \mathrm{T}=298.15 \mathrm{~K}, 150 \mathrm{rpm})$.

The results show that the minimal amount of $\mathrm{MB}$ adsorbed was at $\mathrm{pH}=4$, that it increased with $\mathrm{pH}$ and remained almost constant over the $\mathrm{pH}$ range of 7-9. Similar trends have been reported by other studies of $\mathrm{MB}$ removal using lignocellulosic materials [25, 34, 35]. The unfavourable effect of low $\mathrm{pH}$ on $\mathrm{MB}$ removal can probably be attributed to the presence of positively charged $\mathrm{H}^{+}$ions that compete with $\mathrm{MB}$ cations for adsorption sites. Furthermore, $\mathrm{pH}_{\mathrm{pzc}}$ of poplar sawdust was found to be 7.1 , so at $\mathrm{pH}$ higher than 7.1 its surface will be charged negatively and interact more readily with cationic dye MB.

\section{Adsorption Behaviour of Poplar Sawdust (Isotherm Studies)}

The adsorption isotherms describe the distribution of the adsorbate between the liquid and solid phase at the adsorption equilibrium at a constant temperature. They also offer insight into the adsorption capacity of the adsorbent for the removal of adsorbate from an aqueous solution. In this study, linear forms of Langmuir and Freundlich isotherm models were used to quantify the adsorption capacity of poplar sawdust.

Langmuir isotherm model is the most frequently used model and it presumes the occurrence of adsorption at specific adsorbent homogenous sites as a monolayer, single adsorption mechanism, uniform adsorption energy along the adsorbent surface and no interaction between the adsorbed molecules of the adsorbate [36]. The linear form of the Langmuir isotherm equation used is given by the following equation:

$$
\frac{\gamma_{\mathrm{e}}}{q_{\mathrm{e}}}=\frac{1}{q_{\mathrm{m}}} \cdot \gamma_{\mathrm{e}}+\frac{1}{K_{\mathrm{L}} \cdot q_{\mathrm{m}}}
$$

where $\gamma_{e}\left(\mathrm{mg} \cdot \mathrm{dm}^{-3}\right)$ is the equilibrium concentration, $q_{e}$ $\left(\mathrm{mg} \cdot \mathrm{g}^{-1}\right)$ is the amount of adsorbed dye per unit mass of adsorbate, $\mathrm{q}_{\mathrm{m}}\left(\mathrm{mg} \cdot \mathrm{g}^{-1}\right)$ is the maximum amount of adsorbed dye (monolayer adsorption capacity) and $\mathrm{K}_{\mathrm{L}}\left(\mathrm{dm}^{3} \cdot \mathrm{mg}^{-1}\right)$ is the Langmuir constant related to the free energy of adsorption. $q_{m}$ and $K_{L}$ can be determined from the plot of $\gamma_{e} /$ $q_{e}$ against $\gamma_{e}$ (Figure 8A). The Langmuir isotherm parameters are given in Table 3 . The dimensionless constant called equilibrium parameter $R_{L}$ indicates the type of isotherm to be unfavourable $\left(R_{L}>1\right)$, favourable $\left(0<R_{L}<1\right)$, linear $\left(R_{L}=1\right)$ or irreversible $\left(R_{L}=0\right)[7]$. It can be calculated as follows:

$$
R_{\mathrm{L}}=\frac{1}{1+K_{\mathrm{L}} \cdot \gamma_{0}}
$$

where $\gamma_{0}\left(\mathrm{mg} \cdot \mathrm{dm}^{-3}\right)$ is the highest initial dye concentration.
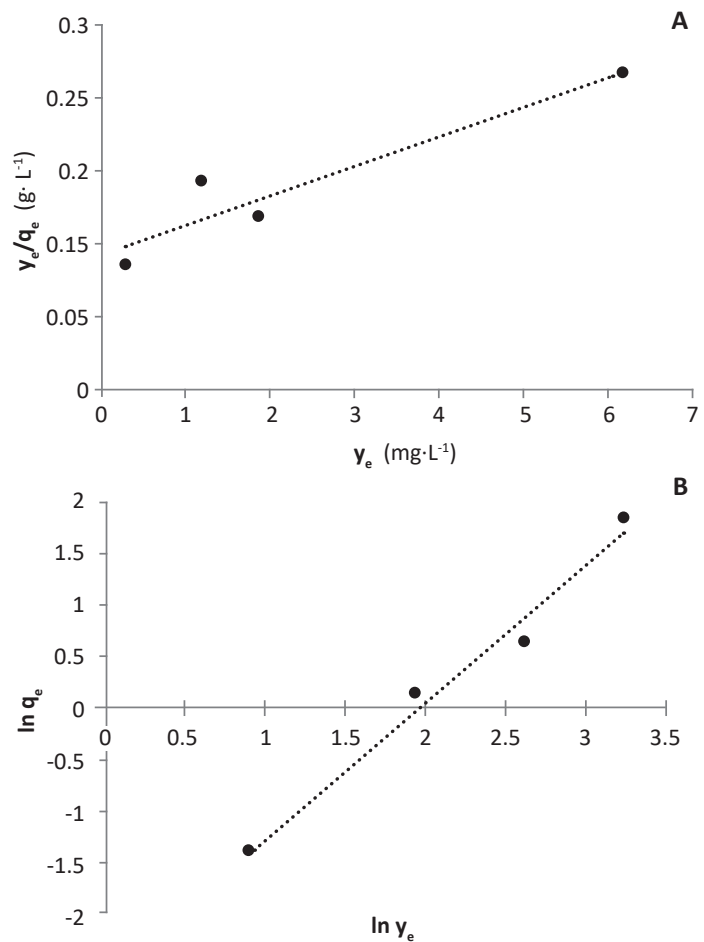

FIGURE 8. Langmuir (A) and Freundlich (B) isotherms of $M B$ adsorption onto poplar sawdust at $298.15 \mathrm{~K}$.

The $R_{L}$ value in this study was 0.045 , confirming that $M B$ adsorption onto poplar sawdust under the studied conditions was a favourable process. When experimentally obtained $q_{m_{\text {exp }}}$ values were compared to the $q_{m_{-} \text {cal }}$ values calculated based on the given Langmuir equation, a discrepancy could be seen. However, as already mentioned, experimentally obtained adsorption capacities $\left(q_{m_{\text {exp }}}\right)$ in this study are comparable to those reported by other authors (Table 2). 
TABLE 3. Isotherm parameters for the removal of MB by poplar sawdust at $298.15 \mathrm{~K}$.

\begin{tabular}{lc}
\hline Isotherm model & $298.15 \mathrm{~K}$ \\
\hline Langmuir & \\
\hline $\mathrm{q}_{\mathrm{m}_{\text {_exp }}}\left(\mathrm{mg} \cdot \mathrm{g}^{-1}\right)$ & 21.900 \\
$\mathrm{q}_{\mathrm{m}_{\text {cal }}\left(\mathrm{mg} \cdot \mathrm{g}^{-1}\right)}$ & 42.373 \\
$\mathrm{~K}_{\mathrm{L}}\left(\mathrm{dm}^{3} \cdot \mathrm{mg}^{-1}\right)$ & 0.213 \\
$\mathrm{R}_{\mathrm{L}}$ & 0.049 \\
$\mathrm{R}^{2}$ & 0.893 \\
\hline Freundlich & \\
\hline $\mathrm{K}_{\mathrm{F}}\left(\mathrm{mg} \cdot \mathrm{g}^{-1}\right)\left(\mathrm{mg} \cdot \mathrm{dm}^{-3}\right)^{1 / \mathrm{n}}$ & 0.075 \\
$\mathrm{n}$ & 0.744 \\
$\mathrm{R}^{2}$ & 0.979 \\
\hline
\end{tabular}

The Freundlich isotherm model assumes the nonideal adsorption on heterogeneous surfaces and multilayer adsorption and interaction between the adsorbed molecules [37]. The linear form of the Freundlich equation is given as:

$$
\ln q_{\mathrm{e}}=\ln K_{\mathrm{F}}+\frac{1}{n} \ln \gamma_{\mathrm{e}}
$$

where $\mathrm{q}_{\mathrm{e}}\left(\mathrm{mg} \cdot \mathrm{g}^{-1}\right)$ is the amount of dye adsorbed at equilibrium and $\gamma_{e}\left(\mathrm{mg} \cdot \mathrm{dm}^{-3}\right)$ is the equilibrium concentration of dye in the solution. Freundlich isotherm constants $\mathrm{K}_{\mathrm{F}}$ and $\mathrm{n}$ indicate the adsorption capacity $\left(\mathrm{K}_{\mathrm{F}}\right)$ and whether the adsorption process is favourable or not $(\mathrm{n})$. The Freundlich constants are given in Table 3. The values of $n$ indicate that the adsorption is linear when $n=1, n<1$ indicates that adsorption is a chemical process, while $n>1$ indicates favourable adsorption that is a physical process [38]. The results given in Figure $8 \mathrm{~B}$ and Table 3 indicate that the adsorption of $\mathrm{MB}$ onto poplar sawdust is favourable and can be described in terms of the Freundlich isotherm model.

\section{CONCLUSIONS}

Waste wood biomass of ten tree species used in this study proved to be effective for the removal of synthetic dye methylene blue (MB) from an aqueous solution, achieving high removal percentage ranging from 93.25 to $98.50 \%$. Poplar sawdust, the most effective of all tested tree species, was used in further adsorption experiments. The results showed that the percentage of dye removal increased with the increase of biosorbent concentration and contact time. The amount of MB removed at equilibrium increased from 2.41 to $21.90 \mathrm{mg} \cdot \mathrm{g}^{-1}$ with the increase of initial dye concentration $\left(10-100 \mathrm{mg} \cdot \mathrm{dm}^{-3}\right)$. The effect of $\mathrm{pH}$ was investigated over the $\mathrm{pH}$ range from 4 to 9 , whereas the minimal amount of $\mathrm{MB}$ adsorbed was at $\mathrm{pH}=4$. After that, it increased up to $\mathrm{pH}=6$ and then remained constant. The obtained equilibrium data were fitted to Langmuir and Freundlich isotherm models, and it was shown that the MB adsorption process could be interpreted in terms of both adsorption isotherms. However, the equilibrium data seem to be somewhat better fitted with the Freundlich isotherm equation. The overall results suggest that waste wood biomass represents a low-cost lignocellulosic adsorbent that has a potential to be used as an alternative to costly conventional adsorbents. However, further research should be undertaken to investigate the possibility of adsorption capacity improvement by different modification techniques, as well as the MB removal from synthetic and real wastewater samples.

\section{Acknowledgments}

The authors would like to thank Croatian Forests Ltd. for the kind donation of waste wood biomass.

\section{REFERENCES}

1. CROATIAN FORESTS LTD 2013 Forests in Croatia. URL: $\quad$ http://www.hrsume.hr/index.php/en/forests/ general/forests-in-croatia (19 July 2018)

2. EUROPEAN COMMISION 2018 Forest-based industries. URL: https://ec.europa.eu/growth/sectors/raw-materials/ industries/forest-based en (19 July 2018)

3. ANNUAR MSM, ADNAN S, VIKINESWARY S, CHISTI Y 2009 Kinetics and energetics of azo dye decolorization by Pycnoporus sanguineus. Water Air Soil Poll 202 (1-4): 179188. DOI: https://doi.org/10.1007/s11270-008-9968-5

4. HAMEED BH, AHMAD AA 2009 Batch adsorption of methylene blue from aqueous solution by garlic peel, an agricultural waste biomass. J Hazard Mater 164 (2-3): 870875. DOI: https://doi.org/10.1016/i.jhazmat.2008.08.084

5. RAFATULLAH M, SULAIMAN O, HASHIM R, AHMAD A 2010 Adsorption of methylene blue on low-cost adsorbents: A review. J Hazard Mater 177 (1-3): 70-80. DOI: https://doi. org/10.1016/j.jhazmat.2009.12.047
6. SHUKLA A, ZHANG Y-H, DUBEY P, MARGRAVE JL, SHUKLA SS 2002 The role of sawdust in the removal of unwanted materials from water. J Hazard Mater 95 (1-2): 137-152. DOI: https://doi.org/10.1016/S0304-3894(02)00089-4

7. AHMAD A, RAFATULLAH $M$, SULAIMAN O, IBRAHIM MH, HASHIM R 2009 Scavenging behaviour of meranti sawdust in the removal of methylene blue from aqueous solution. J Hazard Mater 170 (1): 357-365. DOI: https://doi. org/10.1016/i.jhazmat.2009.04.087

8. DULMAN V, CUCU-MAN SM 2009 Sorption of some textile dyes by beech wood sawdust. J Hazard Mater 162 (2-3): 1457-1464. DOI: https://doi.org/10.1016/j. jhazmat.2008.06.046

9. KHAN TA, SHARMA S, KHAN EA, MUKHLIF AA 2014 Removal of Congo red and basic violet 1 by chir pine (Pinus roxburghii) sawdust, a saw mill waste: batch and column studies. Toxicol Environ Chem 96 (4): 555-568. DOI: https:// doi.org/10.1080/02772248.2014.959017 
10. RAMESH ST, GANDHIMATHI R, ELAVARASI TE, ISAI THAMIZH R, SOWMYA K, NIDHEESH PV 2014 Comparison of methylene blue adsorption from aqueous solution using spent tea dust and raw coir pith. Global NEST J 16 (1): 146159. DOI: https://doi.org/10.30955/gnj.001248

11. GINIMUGE PR, JYOTHI SD 2010 Methylene blue: Revisited. $J$ Anaesth Clin Pharmacol 26 (4): 515-520

12. VELIĆ N, TIŠMA M, JOZIĆ I, ZELIĆ B, SUDAR R, KELEKOVIĆ S, DOMAĆINOVIĆ A 2013 Solid-state fermentation of different lignocellulose substrates using Phanerochaete chrysosporium. In: Jukić A (ed) 14th Ružička days "Today science - tomorrow industry", Proceedings of 14th Ružička days "Today science - tomorrow industry", Vukovar, Croatia, 13-15 September 2012. Croatian Society of Chemical Engineers, Josip Juraj Strossmayer University of Osijek, Faculty of Food Technology Osijek, Zagreb and Osijek, Croatia, pp 187-192

13. BUREVKSA KA, MEMEDI $\mathrm{H}$, LISICHKOV K, KUVENDZIEV S, MARINKOVSKI M, RUSESKA G, GROZDANOV A 2017 Biosorption of nickel ions from aqueous solutions by natural and modified peanut husk: equilibrium and kinetics. Water Environ J 32 (2): 276-284. DOI: https://doi. org/10.1111/wej.12325

14. FOSTER CE, MARTIN TM, PAULY M 2010 Comprehensive compositional analysis of plant cell walls (lignocellulosic biomass) part II: Carbohydrates. J Vis Exp 37: 1837. DOI: https://doi.org/10.3791\%2F1837

15. NACU G 2015 Studies on the use of cellulosic waste to reduce environmental pollution. PhD thesis, Technical University "Gheorghe Asachi" of Iaşi, Iaşi, Romania

16. NACU G, BULGARIU L 2017 Sawdust - sustainable low-cost adsorbent for environmental remediation. In: Stefan E, Olaf $\mathrm{K}$ (eds) Sawdust Properties, Potential Uses and Hazards, Nova Science Publishers, Hauppauge, USA, pp 111-146

17. SJOSTROM E 1993 Wood Chemistry. Fundamentals and Applications, 2nd ed., Academic Press, San Diego, USA, $292 \mathrm{p}$

18. SHEBANI AN, VAN REENEN AJ, MEINCKEN M 2008 The effect of wood extractives on the thermal stability of different wood species. Thermochim Acta 471 (1-2): 43-50. DOI: https://doi.org/10.1016/i.tca.2008.02.020

19. VOIPIO R, LAAKSO T 1992 Chemical composition of the above-ground biomass of small-sized trees. Folia Forestalia 789: 1-22. URL: http://urn.fi/URN:ISBN:951-40-1202-X

20. HYTÖNEN J, NURMI J 2015 Heating value and ash content of intensively managed stands. Wood Res 60 (1): 71-82

21. ABDOLALI A, GUO WS, NGO HH, CHEN SS, NGUYEN NC, TUNG KL 2014 Typical lignocellulosic wastes and byproducts for biosorption process sin water and wastewater treatment. A critical review. Bioresour Technol 160: 57-66. DOI: https://doi.org/10.1016/i.biortech.2013.12.037

22. FIOL N, VILLAESCUSA I 2009 Determination of sorbent point of zero charge: usefulness in sorption studies. Environ Chem Lett 7 (1): 79-84. DOI: https://doi.org/10.1007/ s10311-008-0139-0

23. O'CONNELL DW, BIRKINSHAW C, O'DWYER TF 2008 Heavy metal adsorbents prepared from the modification of cellulose: A review. Bioresour Technol 99 (15): 243-250. DOI: https://doi.org/10.1016/i.biortech.2008.01.036

24. PISTORIUS AMA, DeGRIP WJ, EGOROVA-ZACHERNYUK TA 2009 Monitoring of Biomass Composition From Microbiological Sources by Means of FT-IR Spectroscopy. Biotechnol Bioeng 103 (1): 123-129. DOI: https://doi. org/10.1002/bit.22220
25. KEZERLE A, VELIĆ N, HASENAY D, KOVAČEVIĆ D 2018 Lignocellulosic Materials as Dye Adsorbents: Adsorption of Methylene Blue and Congo Red on Brewers' Spent Grain. Croat Chem Acta 91 (1): 53-64. DOI: https://doi. org/10.5562/cca3289

26. LAING IG 1991 The impact of effluent regulations on the dyeing industry. Rev Prog Colouration 21 (1): 56-71. DOI: https://doi.org/10.1111/i.1478-4408.1991.tb00081.x

27. SHELLEY TR 1994 Dye pollution clean-up by a synthetic mineral. Int Dyer 79: 26-31

28. WANYONYI WC, ONYARI JM, SHIUNDU PM 2014 Adsorption of Congo Red Dye from Aqueous Solutions Using Roots of Eichhornia crassipes: Kinetic and Equilibrium Studies. Energy Procedia 50: 862-869. DOI: https://doi. org/10.1016/j.egypro.2014.06.105

29. VELIĆ N, MARČEK T, JURIĆ T, PETRINOVIĆ K, HASENAY D, BEGOVIĆ L, SLAČANAC V 2015 A survey of different bioadsorbents for removal of malachite green and methylene blue dyes from aqueous solutions. In: Šubarić D, Jukić A (eds) 15th Ružička days "Today science - tomorrow industry", Proceedings of 15th Ružička days "Today science - tomorrow industry", Vukovar, Croatia, 11-12 September 2014. Josip Juraj Strossmayer University of Osijek, Faculty of Food Technology Osijek, Croatian Society of Chemical Engineers, Osijek and Zagreb, Croatia, pp 424-432

30. ANSARI R, MOSAYEBZADEH 2010 Removal of Basic Dye Methylene Blue from Aqueous Solutions Using Sawdust and Sawdust Coated with Polypyrrole. J Iran Chem Soc 7 (2): 339-350. DOI: https://doi.org/10.1007/BF03246019

31. GARG VK, AMITA M, KUMAR R, GUPTA R 2004 Basic dye (methylene blue) removal from simulated wastewater by adsorption using Indian Rosewood sawdust: a timber industry waste. Dyes Pigm 63 (3): 243-250. DOI: https:// doi.org/10.1016/i.dyepig.2004.03.005

32. OFOMAJA AE 2009 Equilibrium sorption of methylene blue using mansonia wood sawdust as biosorbent. Des Water Treat 3: 1-10. DOI: https://doi.org/10.5004/dwt.2009.433

33. FERRERO F 2007 Dye removal by low-cost adsorbents: Hazelnut shells in comparison with wood sawdust. J Hazard Mater 142 (1-2): 144-152. DOI: https://doi.org/10.1016/j. hazmat.2006.07.072

34. HAMDAOUI O 2006 Batch study of liquid-phase adsorption of methylene blue using cedar sawdust and crushed brick. J Hazard Mater 135 (1-3): 264-273. DOI: https://doi. org/10.1016/i.jhazmat.2005.11.062

35. BATZIAS FA, SIDIRAS DK 2007 Simulation of dye adsorption by beech sawdust as affected by $\mathrm{pH}$. J Hazard Mater 141 (3): 668-679. DOI: https://doi.org/10.1016/j. jhazmat.2006.07.033

36. SOTO ML, MOURE A, DOMÍNGUEZ H, PARAJÓ JC 2011 Recovery, concentration and purification of phenolic compounds by adsorption: A review. J Food Eng 105 (1): 1-27. DOI: https://doi.org/10.1016/i.jfoodeng.2011.02.010

37. KATAL R, BAEI MS, RAHMATI HT, ESFANDIAN H 2012 Kinetic, isotherm and thermodynamic study of nitrate adsorption from aqueous solution using modified rice husk. J Ind Eng Chem 18 (1): 295-302. DOI: https://doi.org/10.1016/i. jiec.2011.11.035

38. SADAF S, BHATTI HN, NAUSHEEN S, NOREEN S 2014 Potential Use of Low-Cost Lignocellulosic Waste for the Removal of Direct Violet 51 from Aqueous Solution: Equilibrium and Breakthrough Studies. Arch Environ Contam Toxicol 66 (4): 557-571. DOI: https://doi. org/10.1007/s00244-013-9992-3 